\title{
In- vitro Antidiabetic and Anthelmintic Activity of Hydroalcoholic Extract of Impatiens Balsamina Roots
}

\author{
Yasodha, Tandrima $\mathrm{M}^{1^{*}}$, Swapna $\mathrm{G}^{1}$, Ankitha $\mathrm{M}^{1}$, Vishal $\mathrm{T}^{1}$, Bhagya Sri $\mathrm{P}^{1}$
}

${ }^{1}$ Dhanvanthri College of Pharmaceutical Sciences, Mahabubnagar, Telangana- 509001, India

\begin{abstract}
Article History
Received: 25.02.2021

Accepted: 08.03.2021

Published: 12.03 .2021

Journal homepage:

https://www.easpublisher.com

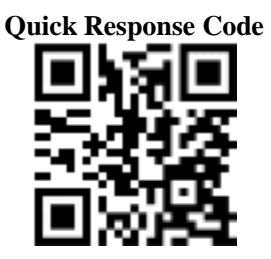

Abstract: Impatiens balsamina roots were collected, dried and grinded to a corase powder. The hydroethanolic extract was prepared by hot percolation technique using Soxhlet Apparatus. The prepared extract was then evaluated for its preliminary and phytochemical screening. The phytochemical screening reveals the presence of several secondary metabolites like flavonoids, saponins, tannins, phenols, glycosides, terpenoids. The extract was evaluated for in-vitro antidiabetic activity using alpha-amylase inhibition method using Acarbose as a standard. The extract has shown its $\mathrm{IC}_{50}$ value at $0.316 \pm 0.002 \mathrm{mg} / \mathrm{ml}$, while Acarbose having $\mathrm{IC}_{50}$ value at $0.206 \pm 0.001 \mathrm{mg} / \mathrm{ml}$. The extract was further tested for anthelmintic activity by adulticidal activity using Albendazole as a standard. The extract exhibited significant anthelmintic activity and was dose dependent.

Keywords: Antidiabetic activity, Anthelmintic activity, Impatiens balsamina. Hydroethanolic extract.

Copyright (C) 2021 The Author(s): This is an open-access article distributed under the terms of the Creative Commons Attribution 4.0 International License (CC BY-NC 4.0) which permits unrestricted use, distribution, and reproduction in any medium for non-commercial use provided the original author and source are credited.
\end{abstract}

\section{INTRODUCTION}

In India, drugs of herbal origin have been used in traditional systems of medicines such as Unani and Ayurveda since ancient times. The drugs are derived either from the whole plant or from different organs like leaves, stem, bark, root, flower, and seed [1]. Herbal medicine has a long history in the treatment of several types of diseases [2]. Raw drugs are collected in larger quantities and traded in the market as the raw material for many herbal industries [3].

Jewel weed, scientifically known as Impatiens balsamina Linn. Belonging to family Balsaminaceae. The family consist of more than 1,000 species, but only two genera are recognized [4]. It is an annual, erect herb having 30- $90 \mathrm{~cm}$ height. In India it is commonly cultivated as garden plant throughout tropical and subtropical parts, and commonly seen on the boarders of rice fields. Whole plants and flowers are used for medicinal and cosmetic purpose [5]. The flowers are pink, red, mauve, lilac, or white. Impatiens balsamina (English name-Rose balsam, Hindi name - (Gul mehendi).

Many compounds have been isolated from $I$. balsamina including phenolics, flavonols, anthocyanin pigments, and saponins [6]. The genus Impatiens is rich in organic acids, Anthraquinones and Flavonoids.
Impatiens balsamina L. has been used as indigenous medicine in Asia for the treatment of rheumatism, fractures and fingernail inflammation. Different parts of the plant are used as traditional remedies for disease and skin afflictions [7]. Juice from the leaves is used to treat warts and snakebite, and the flower is applied to burns.

The extracts of $I$. balsamina also showed a long lasting skin moisturizing effect and prevent dryness, rough skin chap, dandruff and splitting hair ends, hence are used to prepare lotions, creams, hair tonics, cosmetics, bath preparations and detergents [8, 9]. Different parts of the plant are used to treat disease and skin afflictions; the leaves, seeds and stems are also edible if cooked. Modern analytical, chemical and pharmacological studies have revealed presence of flavonol and naphthoquinone derivatives [10]. These constituents have strong antimicrobial, antianaphylaxis, anti-inflammatory, anti-dermatitis activities [11]. The alcoholic extract of the flowers has been found to show antibiotic activity for against scleroting, fructicola and other pathogenic fungi and bacteria [6]. It is reported to be useful for pains in the joints. The seeds of Impatiens balsamina Linn are edible. The successive seed extracts have shown promising antibacterial and antifungal activities [12]. In addition, various parts of the plant has also been 
reported to possess wide range of pharmacological activities such as antifungal, analgesic, antioxidant, anticancer, antitumor, anti-inflammatory, antipruritic, antidermatitic, mosquito larvicidal activity[12,13-17].

This article intends to evaluate the in-vitro antidiabetic and anthelmintic activity of root part of Impatiens balsamina. The extensive literature survey shows that both these activities are not yet reported in the root part. Hence the effort has been taken to do so on the hydroethanolic extract of the roots.

\section{Materials ANd Methods}

The fresh roots of Impatiens balsamina were collected from the garden of Tripuravaram (Vil), Kodada, Ananthagiri (Mandal), Suryapet (Dist.), Telangana. The part was authenticated by Dr. D.S.R. Rajender Singh, Principal and Associate Professor, Dept. of Botany, S.V. Gov. Arts and Science Degree College.

\section{Preparation of extract}

About $50 \mathrm{gm}$ of the coarsely powdered roots was suspended in hydroalcoholic solvent (3:2 ratio) in a round bottom flask and kept for extraction using Soxhlet apparatus [18, 19]. This extraction was continued until the solvent became colourless. The hydroalcoholic extract was collected, evaporated under controlled temperature on a hot plate and stored in dessicator for further screenings like solubility test, phytochemical investigations, anthelmintic activity, and antidiabetic activity.

\section{Phytochemical Analysis of the Extract [20-21]}

\section{Test for Carbohydrates}

A. Molisch test: To the $1 \mathrm{ml}$ of test solution add two drops of alpha- Naphthol and then add concentrated Sulphuric acid down the side of the tube to form the ring at the interface of the two layers

B. Barfoed's test: To the test solution add $1 \mathrm{ml}$ of Barfoed's reagent and heat it for $3 \mathrm{~min}$.the production of reddish brown precipitate indicates the presence of carbohydrates.

C. Fehling's test: to the $1 \mathrm{ml}$ of test solution add $1 \mathrm{ml}$ of Fehling's solution and place it in a boiling water bath for few minutes. The production of yellowish-brown precipitate indicates the presence of carbohydrates.

D. Benedict's test: to the $2 \mathrm{ml}$ of test solution, $2 \mathrm{ml}$ of Benedict's reagent is added, mix it well and boil for 1 minute. Place it in cool water and observe the colour change.

\section{Test for alkaloids}

A. Dragendorff's test: To $2 \mathrm{mg}$ of the extract 5 $\mathrm{ml}$ of dis. water was added, $2 \mathrm{M}$ Hydrochloric acid was added until an acid reaction occurs. To this $1 \mathrm{ml}$ of Dragendorff's reagent was added. Formation of orange or orange red precipitate indicates the presence of alkaloids.

B. Hager's test: To $2 \mathrm{mg}$ of the extract taken in a test tube, a few drops of Hager's reagent were added. Formation of a yellow precipitate indicates the presence of alkaloids.

C. Wagner's test: $2 \mathrm{mg}$ of the extract was acidified with $1.5 \% \mathrm{v} / \mathrm{v}$ of hydrochloric acid and a few drops of Wagner's reagent were added. A yellow or brown precipitate indicates the presence of alkaloids.

\section{Test for Proteins}

A. Biuret test: To $3 \mathrm{ml}$ Test solution add $4 \%$ sodium hydroxide and few drops of $1 \%$ copper sulphate solution. Violet or pink colour appears.

B. Millon's test: Mix 3ml Test solution with $5 \mathrm{ml}$ Millon's reagent, white precipitate turns brick red or the precipitate dissolves giving red colored solution.

C. Xanthoprotein test: Mix 3ml Test solution with $1 \mathrm{ml}$ concentrated sulphuric acid. White precipitate is formed. Boil mixture. Precipitate turns yellow. Add ammonium hydroxide, ppt. turns orange.

D. Precipitation test: The test solution gives white colloidal ppt. with following reagents: a) absolute alcohol, b) 5\% Copper sulphate solution, d) 5\% lead acetate, e) 5\% Ammonium sulphate.

\section{Test for Aminoacids}

A. Ninhydrin test: Heat $3 \mathrm{ml}$ test solution and 3 drops of 5\% Ninhydrin solution in boiling water bath for $10 \mathrm{~min}$. purple or bluish colour appears.

B. Test for tyrosine: heat $3 \mathrm{ml}$ test solution and 3 drops Millons reagent. Solution shows dark red colour.

C. Test for tryptophan: To $3 \mathrm{ml}$ test solution add few drops of glyoxalic acid and concentrated sulphuric acid. Reddish violet ring appears at junction of the two layers.

D. Test for cysteine: To $5 \mathrm{ml}$ test solution add few drops of $40 \%$ sodium hydroxide and $10 \%$ lead acetate solution, black ppt. of lead sulphate is formed.

\section{Test for Phenols}

A. Ellagic Acid Test: The T.S. was treated with a few drops of $5 \%(\mathrm{w} / \mathrm{v})$ glacial acetic acid and $5 \%$ $(\mathrm{w} / \mathrm{v})$ sodium nitrate solution. The solution turned 
muddy or Niger brown precipitate occurred in the extract. It indicates the presence of phenol solution.

B. Ferric chloride test: $0.5 \mathrm{ml}$ of Ferric chloride $(\mathrm{w} / \mathrm{v})$ solution was added in $2 \mathrm{ml}$ of tests solution, formation of an intense colour indicates the presence of phenols.

C. Hot water test: Deep the mature plant part in a beaker containing hot water, warm it for a minute development of black or brown colour ring at the junction of dipping indicates the presence of phenols.

\section{Test for Flavonoids}

A. Shinoda test: In a test tube containing 0.5 $\mathrm{ml}$ of the extract 10 drops of dilute hydrochloric acid followed by a small piece of magnesium were added. Formation of pink, reddish or brown colour indicates the presence of flavonoids.

B. Ferric chloride test: Test solution with a few drops of ferric chloride solution shows intense green colour.

C. Zinc-Hydrochloric acid reduction test: Test solution with zinc dust and a few drops of hydrochloric acid shows magenta red colour.

D. Alkaline reagent test: Test solution when treated with sodium hydroxide solution, shows an increase in the intensity of yellow colour which becomes colourless on the addition of a few drops of dilute acid.

E. Lead acetate solution test: Test solution with a few drops of lead acetate $(10 \%)$ solution gives a yellow precipitate.

\section{Test for Triterpenoids}

A. Liebermann - Burchard's test (LB test): 2 mg of dry extract was dissolved in acetic anhydride, heated to boiling, cooled and then $1 \mathrm{ml}$ of concentrated Sulphuric acid was added along the sides of the test tube. Formation of a violet colored ring indicates the presence of triterpenoids.

B. Salkowaski test: When a few drops of concentrated sulphuric acid were added to the test solution, shaken and allowed to stand, lower layer turns yellow indicates the presence of triterpenoids.

\section{Test for Saponins}

A. Foam test: In atest tube containing about 5 $\mathrm{ml}$ of extract, a drop of sodium bicarbonate solution was added. The test tube was shaken vigorously and left for 3 minutes. Formation of honeycomb like froth indicates the presence of saponins.

\section{Test for Steroids}

A. Liebermann-Burchard's test: $2 \mathrm{mg}$ of dry extract was dissolved in acetic anhydride, heated to boiling, cooled and then $1 \mathrm{ml}$ of concentrated sulphuric acid was added along the sides of the test tube. Formation of green colour indicates the presence of steroids.

B. Salkowaski reaction: $2 \mathrm{mg}$ of dry extract was shaken with chloroform, to the chloroform layer sulphuric acid was added slowly by the sides of the test tube. Formation of red colour indicates the presence of steroids.

C. Sulphur test: pinch of sulphur powder added to test solution it sinks to the bottom it indicates the presence of steroids

\section{Test for Tannins}

A. Ferric chloride test: To 1-2 $\mathrm{ml}$ of the extract, few drops of $5 \% \mathrm{w} / \mathrm{v}$ Ferric chloride solution were added. A green colour indicated the presence of gallotannins, while brown colour indicates the presence of pseudotannins.

B. Gelatin test: Test solution when treated with a gelatin solution gives white precipitate colour. This indicates the presence of a naphthoquinone.

\section{Test for Glycosides}

A. Keller-Killiani test: The test solution was treated with a few drops of ferric chloride solution and mixed. When concentrated sulphuric acid containing ferric chloride solution was added, it forms two layers, lower layer reddish brown and upper acetic acid layer turns bluish green.

B. Legal's test: Test solution when treated with pyridine (made alkaline by adding sodium nitroprusside solution) gives pink to red colour.

C. Baljet'stest: Athick section shows yellow to orange colour with sodium picrate

D. Liberman's test: mix $3 \mathrm{ml}$ extract with $3 \mathrm{ml}$ acetic anhydride. Heat and cool. Add few drops of concentrated. Blue colour appears.

\section{Test for Anthraquinone Glycosides}

A. Borntrager's test for anthraquinone glycosides: to $3 \mathrm{ml}$ of extract, add dilute sulphuric acid. Boil and filter. To cold filtrate add equal volume of benzene or chloroform. Shake well separate the organic solvent add ammonia ammonical layer turns pink or red.

B. Modified borntrager's test for C-glycosides: to $5 \mathrm{ml}$ of extract add $5 \mathrm{ml} 5 \%$ Ferric chloride and $5 \mathrm{ml}$ dilute hydrochloric acid. Heat for $5 \mathrm{~min}$ in boiling water bath. Cool and add benzene or any organic solvent. Shake well. Separate organic layer, add equal volume dilute ammonia. Ammonical layer shows pinkish red colour. 


\section{Test for Cyanogenetic Glycosides}

A. Grignard reagent or sodium picrate test: soak a filter paper strip first in $10 \%$ picric acid, then in $10 \%$ sodium carbonate, dry in a conical flask place moistened powdered drug cork it, place the above filter paper strip in the slit in cork. The filter paper turns brick red or maroon.

\section{Test for Coumarin Glycosides}

A. Alcoholic extract when made alkaline, shows blue or green fluorescence.

B. Take moistened dry powder in the test tube. Cover the test tube with filter paper soaked in dilute sodium hydroxide. Keep in water bath. After sometime expose filter paper to Ultra violet Light. It shows yellowish green fluorescence.

\section{c) In-vitro anti-diabetic activity}

\section{Alpha-amylase inhibitory activity}

Alpha-amylase inhibitory activity of extract and fractions was carried out according to the standard method with minor modification. In a test tubes, reaction mixture containing $50 \mu \mathrm{l}$ phosphate buffer $(100 \mathrm{mM}, \mathrm{pH}=6.8), 10 \mu \mathrm{l} \alpha$-amylase $(2 \mathrm{U} / \mathrm{ml})$, and $20 \mu \mathrm{l}$ of varying concentrations of extract $(0.1,0.2,0.3,0.4$, and $0.5 \mathrm{mg} / \mathrm{ml}$ ) was pre incubated at $37^{\circ} \mathrm{C}$ for $20 \mathrm{~min}$. Then, the $20 \mu \mathrm{l}$ of $1 \%$ soluble starch $(100 \mathrm{mM}$ phosphate buffer $\mathrm{pH}$ 6.8) was added as a substrate and incubated further at $37^{\circ} \mathrm{C}$ for $30 \mathrm{~min} ; 100 \mu \mathrm{l}$ of the DNS colour reagent was then added and boiled for $10 \mathrm{~min}$. The absorbance of the resulting mixture was measured using photo colorimeter, Electronics India at $540 \mathrm{~nm}$. Acarbose at various concentrations $(0.1-0.5 \mathrm{mg} / \mathrm{ml})$ was used as a standard. Without test (extract) substance was set up in parallel as control and each experiment was performed in triplicates [22-24]. The results were expressed as percentage inhibition, which was calculated using the formula,

Inhibitory activity $(\%)=(1-\mathrm{As} / \mathrm{Ac}) \times 100$, where,

As is the absorbance in the presence of test substance and Ac is the absorbance of control.

\section{d) In-vitro anthelmintic activity}

\section{Adult Motility Assay (AMA)}

AMA was conducted on mature Pheretima posthuma worms following technique of the test was performed in $5 \mathrm{~cm}$ diameter glass petridish [25-27]. A total of about 75 adult parasites were used in the study. Three concentrations of plant extract was employed plant. Five worms were exposed in triplicate to each of the following treatments in separate petridishes at room temperature $\left(25-30^{\circ} \mathrm{C}\right)$.There were 5 groups as follows:
Group I: Hydroalcoholic extract at $10 \mathrm{mg} / \mathrm{mL}$

Group II: Hydroalcoholic extract $25 \mathrm{mg} / \mathrm{ml}$

Group III: Hydroalcoholic extract at $50 \mathrm{mg} / \mathrm{mL}$

Group IV: Albendazole at 100mg (positive control);

Group V: Water (negative control).

The inhibitions of motility of worms were used as indication of worm mortality or paralysis. Motility of worms was observed and motile worms were counted at different time intervals till $7 \mathrm{hrs}$ post treatment. Worms not showing any motility were picked out and kept in lukewarm water at $40{ }^{\circ} \mathrm{C}$ for 10 minutes and, in case of revival in motility, the observed worms were counted as alive; otherwise, they were counted as dead. The paralytic time and the death time of all the worms were recorded and depicted in Table 5.

\section{RESULT AND DISCUSSIONS}

The hydroethanolic roots extract was then evaluated for phytochemical test to determine the phytoconstituents present in Impatiens balsamina. The screening was done for the presence of all the secondary metabolites, like alkaloids, carbohydrates, flavonoids, steroids, tannins and phenols, proteins and amino acids, glycosides, and saponins etc.

All the results are shown in Table No. 3 indicates the presence of carbohydrates, phenols, tannins, flavonoids, steroids, cardiac glycosides, anthraquinone glycosides, triterpenoids and saponins, while alkaloids, proteins, amino acids, coumarin glycosides have shown negative results. An effective means of lowering the levels of postprandial hyperglycaemia have been offered by alpha-amylase inhibitor. Therefore, to know its phytochemical compounds and anti-diabetic activity by using invitro models. It has been observed that the hydroethanolic root extract possessed antidiabetic activity, which is concentration-dependent i.e., with the increase in the concentration, there is an increase in the activity in a linear fashion. Five concentrations of the hydroethanolic root extract were taken at $0.1,0.2,0.3$, 0.4 and $0.5 \mathrm{mg} / \mathrm{ml}$, were tested for antidiabetic activity by Alpha-Amylase Inhibition method. The results are represented both by tabular way and graphical way indicating 27.07, 29.33, 50.66, 58.56 and 62.26 [Table no. 4 and figure no. 1$]$ percentage inhibition at $0.1,0.2$, $0.3,0.4,0.5 \mathrm{mg} / \mathrm{ml}$ respectively. The extract has shown its $\mathrm{IC}_{50}$ value at $0.316 \mathrm{mg} / \mathrm{ml}$. Acarbose is used as a standard. It is an Alpha- glucosidase inhibitor, which lowers the postprandial blood Type-II diabetes mellitus. It delays the absorption of glucose thereby reducing the risk of macro vascular complications. Acarbose has shown alpha - amylase inhibition with $\mathrm{IC}_{50}$ at 0.206 $\mathrm{mg} / \mathrm{ml}$. The secondary metabolites present in the roots extract are mainly flavonoids, triterpenoids, tannins, anthraquinone glycosides which is responsible for its antidiabetic activity. 
The in-vitro tests using free living stages of parasitic nematodes offer a means of evaluating the anthelmintic activity of new plant compounds. The death time was recorded as 81,30 and 11 mins respectively. This indicates that with increase in concentration, there is an increase in the anthelmintic activity with $50 \mathrm{mg} / \mathrm{ml}$ concentration showing the highest activity. Albendazole is used as a reference drug. The paralytic time and death time recorded for standard was 30 seconds and 1 minute respectively at $100 \mathrm{mg} / \mathrm{ml}$. The root extract has shown the presence of tannins and phenols which is mainly responsible to show its potent anthelmintic activity.

In conclusion, Impatiens balsamina roots were collected to obtain the hydroethanolic extract by hot percolation process. The extract on preliminary investigation showed that it is reddish-brown in colour, with coffee-like smell and semi-solid consistency. The extract is basic and polar in nature obtained from solubility tests. Its qualitative phytochemical analysis shows the presence of secondary metabolites like carbohydrates, tannins and phenolic compounds, triterpenoids, steroids, flavonoids, saponin glycosides, cardiac glycosides and anthraquinone glycosides. Further investigation of pharmacological activities indicated that the extract have potent in vitroantidiabetic and anthelmintic activity. The antidiabetic activity was shown to be dose-dependent, showing maximum activity at $0.5 \mathrm{mg} / \mathrm{ml}$ with $62.26 \pm 0.435$ percent inhibition and $\mathrm{IC}_{50}$ value is $0.316 \pm 0.002 \mathrm{mg} / \mathrm{ml}$, compared against Acarbose having $\mathrm{IC}_{50}$ value at $0.206 \pm 0.001 \mathrm{mg} / \mathrm{ml}$. The secondary metabolites being responsible are mainly flavonoids and anthraquinone glycosides.

The extract has also shown potent anthelmintic activity, which is dose-dependent showing the highest activity at $50 \mathrm{mg} / \mathrm{ml}$, compared against Albendazole as a reference drug. The secondary metabolite tannins and phenolic compounds are considered to be mainly responsible for this activity. These are only preliminary investigations, although more works have been done but still Future prospectives still prevails.

Table-1: Preliminary screening of root extract of impatiens balsamina

\begin{tabular}{|l|l|}
\hline Preliminary screening & Results \\
\hline Colour & Reddish-brown \\
\hline Odour & Coffee like smell \\
\hline Taste & Characteristic \\
\hline State & Semi-solid \\
\hline
\end{tabular}

Table 2: Solubility tests of root extract of impatiens balsamina

\begin{tabular}{|l|l|l|}
\hline Solvent & Observations & Inferences \\
\hline Dimethyl sulphoxide & Soluble & Might be polar or non-polar \\
\hline Ethanol & Sparingly Soluble & Might be polar or non-polar \\
\hline Dimethyl Formamide & Soluble & Might be polar \\
\hline Carbon Tetrachloride & Insoluble & Might be polar \\
\hline Chloroform & Insoluble & Might be polar \\
\hline Petroleum Ether & Insoluble & Might be polar \\
\hline Water & Soluble & Polar \\
\hline
\end{tabular}

Table 3: Phytochemical screening of impatiens balsamina

\begin{tabular}{|l|c|}
\hline Tests & Inference \\
\hline Carbohydrates & + \\
\hline Phenols & + \\
\hline Flavonoids & + \\
\hline Triterpenoids & + \\
\hline Saponins & + \\
\hline Steroids & + \\
\hline Tannins & + \\
\hline Glycosides & + \\
\hline Anthraquinone glycosides & + \\
\hline
\end{tabular}

+ Positive; - Negative 
Table-4: Antidiabetic activity of root extract of impatiens balsamina

\begin{tabular}{|c|c|c|c|}
\hline Sample & $\begin{array}{c}\text { Concentration } \\
(\mathbf{m g} / \mathbf{m l})\end{array}$ & \%inhibition & $\mathbf{I C}_{\mathbf{5 0}} \mathbf{( \mathbf { m g } / \mathbf { m l } )}$ \\
\hline Impatiens balsamina & 0.1 & $27.07 \pm 0.338$ & \\
& 0.2 & $29.33 \pm 0.196$ & \\
& 0.3 & $50.66 \pm 0.360$ & $0.316 \pm 0.002$ \\
& 0.4 & $58.56 \pm 0.241$ & \\
Acarbose & 0.5 & $62.26 \pm 0.435$ & \\
(standard) & 0.1 & $31.83 \pm 0.49$ & \\
& 0.2 & $48.86 \pm 0.288$ & $0.206 \pm 0.001$ \\
& 0.3 & $59.23 \pm 0.118$ & \\
& 0.4 & $66.93 \pm 0.190$ & \\
& 0.5 & $74.8 \pm 0.249$ & \\
\hline
\end{tabular}

Table-5: Anthelmintic activity of root extract of impatiens balsamina

\begin{tabular}{|c|c|c|c|}
\hline Drugs & Concentration & \multicolumn{2}{|c|}{ Average time(min) } \\
\cline { 3 - 4 } & $(\mathbf{m g} / \mathbf{m l})$ & Paralysis & Death \\
\hline Normal & & - & - \\
\hline & 10 & $60 \pm 0.942$ & $81 \pm 1.178$ \\
\cline { 3 - 4 } & 25 & $22 \pm 0.471$ & $30 \pm 0.471$ \\
\cline { 2 - 4 } Hydroethanolic extract (Impatiens balsamina roots) & 50 & $8 \pm 0.707$ & $11 \pm 0.235$ \\
\hline Standard (Albendazole) & 100 & $0.5 \pm 0.009$ & $1 \pm 0.004$ \\
\hline
\end{tabular}

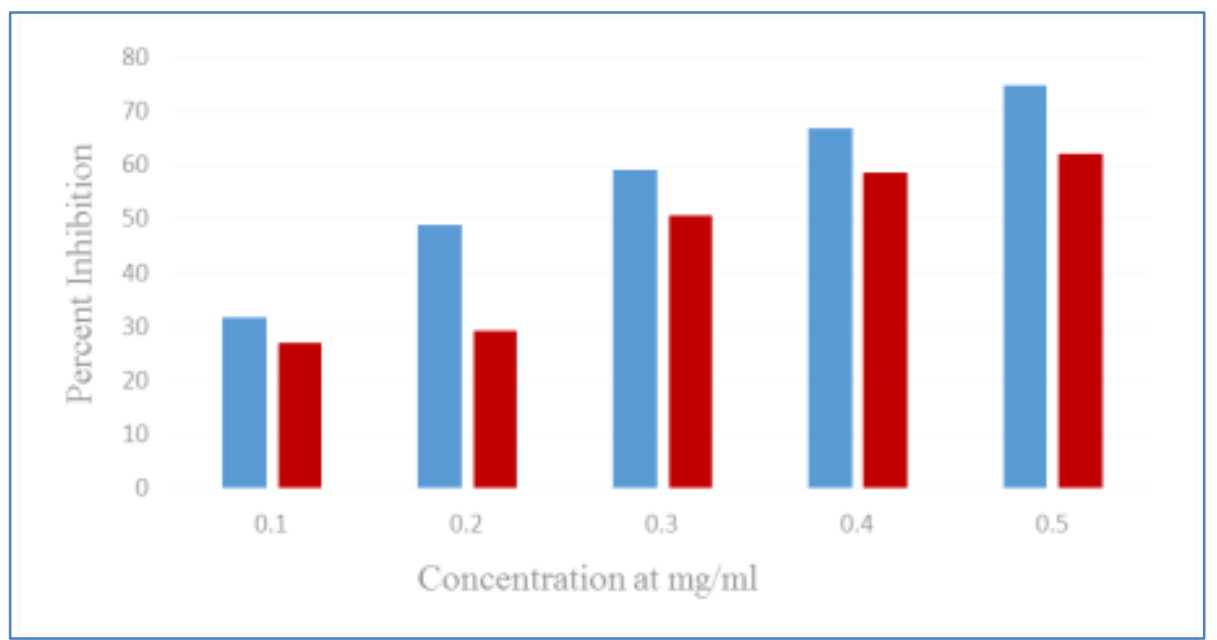

Fig-1: Graph representing the Antidiabetic activity of Impatiens balsamina

Comparison of antidiabetic activity between standard and root extract Acarbose(std.) Root extract of I. Balsamina

\section{ACKNOWLEDGEMENTS}

The financial assistance from Dhanvanthri College of Pharmaceutical Sciences, Mahabubnagar is gratefully acknowledged.

\section{REFERENCES}

1. El Mostaphi, A., El Hartiti, H., Barrahi, M., \& Ouhssine, M. (2018). Antimicrobial Activity of the Essential Oil of an Endemic Plant in Morocco, Impatiens balsamina. J Clin Toxicol, 8(381), 21610495.
2. Bole, S., Shivakumara, Wahengbam, S.S., Rana, N.K., Kundu, S. (2013). Phytochemical Screening and biological activities of Impatiens Balsamina. L Seeds. World Journal of Pharmacy and Pharmaceutical Sciences, 2, 5363-76.

3. Manikandan, A., Rajendran, R., Abirami, M., \& Kongarasi, K. (2016). Antimicrobial activity and phytochemical analysis of Impatiens balsamina Seed (Kaci-T-Tumpai) collected from Coimbatore District, Tamil Nadu, India. International Journal of Pharmaceutical Sciences and Research,7(12), 5039.

4. Janssens, S., Geuten, K., Yuan, Y. M., Song, Y., Küpfer, P., \& Smets, E. (2006). Phylogenetics of Impatiens and Hydrocera (Balsaminaceae) using chloroplast atpB-rbcL spacer sequences. Systematic Botany, 31(1), 171-180. 
5. Shah, K. N., Verma, P., \& Suhagia, B. (2017). A phyto-pharmacological overview on Jewel Weed. $J$ Appl Pharmaceu Sci, 7, 246-252.

6. Kang, S. N., Goo, Y. M., Yang, M. R., Ibrahim, R. I. H., Cho, J. H., Kim, I. S., \& Lee, O. H. (2013). Antioxidant and antimicrobial activities of ethanol extract from the stem and leaf of Impatiens balsamina L.(Balsaminaceae) at different harvest times. molecules, 18(6), 6356-6365.

7. Debashree, N., Subhalakshmi, A., Rita, S., \& Pfuzia, A. (2013). Study of Analgesic and Antiinflammatory Effects of Impatiens balsamina leaves in albino Rats. Int J Pharm Bio Sci, 4(2), 581-587.

8. Meenu, B., Neeraja, E. D., Greeshma, R., \& Alexeyena, V. (2015). Impatiens balsamina: An overview. Journal of Chemical and Pharmaceutical Research, 7(9), 16-21.

9. Sharma, S.K. (1998). 'Use of Lindenbergia muraria leaves and Impatiens balsamina flowers as a substitute for henna'. The journal of the Bombay Natural History Society, 95: 150

10. Shah, A., Keach, J.E., Panichayupakaranant, P. (2018). Anti-diabetic Napthoquinones and their plant resources. Journal Pharmaceutical Chemistry, 66: 483-492.

11. Ding, Z. S., Jiang, F. S., Chen, N. P., Lv, G. Y., \& Zhu, C. G. (2008). Isolation and identification of an anti-tumor component from leaves of Impatiens balsamina. molecules, 13(2), 220-229.

12. Jain, B. (2011). Antimicrobial activity of seed extract of Impatiens balsamina Linn. Current World Environment, 6(2), 299.

13. Baskar, N., Devi, B.P., Jayakar, P. (2012). Anticancer studies on ethanolic extract of Impatiens balsamina, Int.J. of Pharm. Sci, 3; 631-633.

14. Oku, H., Kato, T., \& Ishiguro, K. (2002). Antipruritic effects of 1, 4-naphthoquinones and related compounds. Biological and Pharmaceutical Bulletin, 25(1), 137-139.

15. Govindarajan, M., \& Rajeswary, M. (2014). Mosquito larvicidal properties of Impatiens balsamina (Balsaminaceae) against Anopheles stephensi, Aedes aegypti and Culex quinquefasciatus (Diptera: Culicidae). Journal of Coastal Life Medicine, 2(3), 222-224.

16. Rodriguez, F.V., Hidalgo, O., Gutiérrez, A.L., Weng-Huang, N.T. (2017). In-vitro Anti-oxidant and Anti-microbial activities of ethanolic extract of whole plant of Impatiens balsamina. Ancient Science of Life, 37; 16-23.
17. Neevashnhi, N., Anandarajagopal, K., Sunilson, A. (2017). Anti-inflammatory activity of Impatiens balsamina roots and stems, Scholars Academic Journal of Pharmacy, 6, 368-371.

18. Seo, J., Lee, S., Elam, M. L., Johnson, S. A., Kang, J., \& Arjmandi, B. H. (2014). Study to find the best extraction solvent for use with guava leaves (Psidium guajava L.) for high antioxidant efficacy. Food Science \& Nutrition, 2(2), 174-180.

19. Toudert, N., Zaiter, A., Djilani, S. E., Dada, N., Djilani, A., \& Dicko, A. (2017). Impact of methanol-water ratio of leaf and root extracts of Ampelodesma mauritanicaon the antioxidant activity, and effect of different solvent extraction on phenolic compounds quantification. Acta Sci. Nutr. Health, 1, 3-7.

20. Khandelwal, K.R. (2012). Practical Pharmacognosy, techniques and experiments 22nd ed. India: Nirali Prakashan.

21. Suryawanshi, P., Vidyasagar, G.M. (2016). Phytochemical screening for secondary metabolites of Opuntia dillenii Haw. J Med Plants Stud; 4:3943.

22. Narkhede, M. B., Ajimire, P. V., Wagh, A. E., Mohan, M., \& Shivashanmugam, A. T. (2011). In vitro antidiabetic activity of Caesalpina digyna (R.) methanol root extract. Asian Journal of Plant Science and Research, 1(2), 101-106.

23. Stalin, C., Vivekanandan, K., \& Bhavya, E. (2013). In vitro antidiabetic activity of Cardiospermum halicacabum leaves extracts. Global Journal of Medical Research, 13(7), 41-43.

24. Sangeetha, R., \& Vedasree, N. (2012). In vitro $\alpha$ amylase inhibitory activity of the leaves of Thespesia populnea. International Scholarly Research Notices, 2012.

25. Goswami, S., Pandey, A., Tripathi, P., Singh, A., \& Rai, A. (2011). An in vitro evaluation of the anthelmintic activity of Hedychium spichatum rhizomes and Zingiber zerumbet rhizomes on the Pheritima Posthuma model: A comparative study. Pharmacognosy research, 3(2), 140.

26. Kakade, R.T., Sandu, N., \& Senthilkumar, K.L. (2013). In-vitro anthelmintic activity of leaves and stems extract of Bryophytum sensitium Linn. Asian J. of Plant Sci. and Res, 3: 64-68.

27. Zenebe, S., Feyera, T., \& Assefa, S. (2017). In vitro anthelmintic activity of crude extracts of aerial parts of Cissus quadrangularis L. and leaves of Schinus molle L. against Haemonchus contortus. BioMed research international, 2017.

Cite This Article: Yasodha, Tandrima M et al (2021). In- vitro Antidiabetic and Anthelmintic Activity of Hydroalcoholic Extract of Impatiens Balsamina Roots. EAS J Pharm Pharmacol, 3(2), 38-44. 